\title{
鋼構造物における歪硬化現象について
}

\section{§1. 梗概}

鋼構造物の非弾性域に扝ける挙動に関する最近の研究 報告において，多くの実験結果が理論上の耐力よりしば しば高くなることが指摘され，また，一方で惊高張力鋼 の利用に伴い高張力鋼の $\sigma-\varepsilon$ 特性に基く降伏比と安全率 の考え方に関連する問題が取上げられている。

更に架構の弾・塑性地震店答の解析に用いられる復元 力特性をより的確に把握する意味でも架構の変形特性に 現わ机る歪硬化現象学理解して扝くことが必要である ら。

筆者等は既に鋼構造架構の弾・塑性安定問題の解析に 際し, 歪硬化現象について若干触れてきた。この歪硬化 現象が鋼構造物の耐力あるいは変形性状におよぼす効果 は鋼材自身の $\sigma-\varepsilon$ 特性, 部材あるい澡構の形状, 荷重 条件，応力分布等により変わる。

鋼構造物に関する多数の実験報告のなかでも，鋼構造 部材あるいは架構の終局状態に到る迄に極めて顕著な歪 硬化現象が現われその結果耐力の高まりあるいは变形の 安定性を期待し得ると報告されているものに対し，一方 では，歪硬化現象の効果は余り期待し得ないとする報告 も文り，歪硬化現象に関する統一的な見解が得られてい ない現状といえる。この歪硬化による架構の耐力の高ま りあるいは変形特性におよぼす影響を現実の設計過程に とり入れるべきか否か㼁論の生ずる問題であるが，本 稿で注鋼構造物が非弾性域に入り終局状態に到る迄の挙 動をより正確に理解する意味で鋼構造部材あるいは架構 に現われる歪硬化現象の傾向について解析的考察空試み るものである。

\section{§ 2. $\mathrm{H}-$ 形断面材の曲率関数並びに $m-\beta$ 関数}

\section{$2.1 m-\varphi$ 関数}

解析の対象とする鋼材の応力度一歪度曲線は Fig. 1 に 示すように弾性域, 塑性流動域, 歪硬化域が全て線形で 表現されるものと仮定する。

このように理想化された応力度一歪度曲線の非弾性域 に招ける特性を表わす塑性流動域の長さ $\left(e_{S t}=\varepsilon_{S t} / \varepsilon_{y}\right)$ ， 歪硬化域の立上り勾配 $E_{S t}$ の值を下記のように想定す

* 名古屋大学助教授・工博

** 名古屋工業大学工業教員養成所助教授

*** 名古屋大学助手

（昭和 41 年 11 月 14 日本稿受理，尌論期限昭和 42 年 9 月末日）

\begin{tabular}{|c|c|c|c|c|}
\hline 正会員 & 坂 & 本 & & 順* \\
\hline " & 宮 & 村 & 篤 & 典** \\
\hline " & 渡 & 辺 & 雅 & 生水水 \\
\hline
\end{tabular}

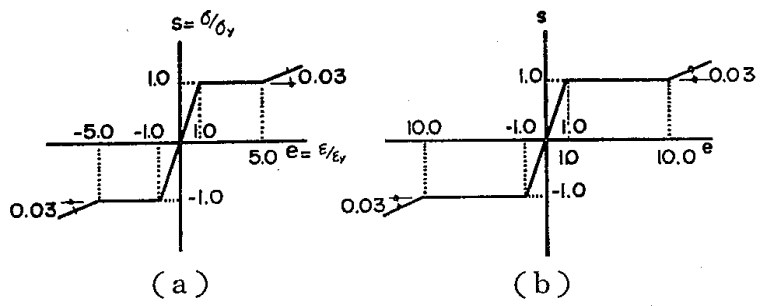

Fig. 1 stress-strain relation

る。

i) $e_{S t}=\varepsilon_{S t} / \varepsilon_{y}=10.0 \quad E_{S t}=0.03 E$

ii) $e_{S t}=\varepsilon_{S t} / \varepsilon_{y}=5.0 \quad E_{S t}=0.03 E$

この 2 種の応力度一歪度特性を考穴以下の考察を進める ことにする。前者の type は (Fig. I a) 標淮構造用鋃 材 (SS 41) の忘力度一歪度曲線を, 後者は塑性流動域の 比較的短い高張力鋼の応力度一歪度曲線を抽象するもの とする。上記の応力度一歪度曲線をもつ H 形断面材のモ ーメントー曲率関係が Fig. 2 に描かれている。同図は Fig. 3 に示される proportion をもつ H 形断面”に一 定軸方向力と強軸まわりの曲げモーメントを受ける場合 のモーメントー軸力ー曲率関倸を数值計算 ${ }^{22}$ した結果であ り, 図中には圧縮側縁歪度が歪硬化開始点 $\left(e_{S t}=10.0\right.$, 15.0）に達した時の境界線が記入されている。歪硬化域 に大ると曲率の増大と共にモーメントも増大するが，一 般にH形断面材の如き板要素で構成された断面では塑性 化が進むに従い不安定現象が生じ，断面の板部の不安定 現象（局部座屈）により限界曲率が規定されることにな る。すなわち，圧縮側フランジの局部座屈で想定される 限界点をってH形断面材の moment capacity とする ことにする。板の局部座屈と限界圧縮歪度に関する研究 は既に Haaijer, G. ${ }^{3)}$, 加藤 ${ }^{4}$ 田中，等により行なわれて おり，局部座屈時の平均限界圧縮歪度 $\varepsilon_{c r}$ は一般に板 の板幅/板厚一比により変化するといえるが，ここでは局 部座屈の限界歪度として $e_{c}=10.0$ 並びに 15.0 を想定 した場合の各々に対応する限界線が Fig. 2 の $m-\varphi$ 曲 線に示されている。

Fig. 4 は上記の限界歪度 $e_{c}=10.0,15.0$ を想定した 時の最大モーメント $\left(M_{p s}\right)$ を基にした interaction relation を描いたものであり，歪硬化現象による部材断面の 抵抗モーメントの増大の性状を示すと共に，これらの曲 線はいずれも歪硬化を考慮しない場合の interaction 


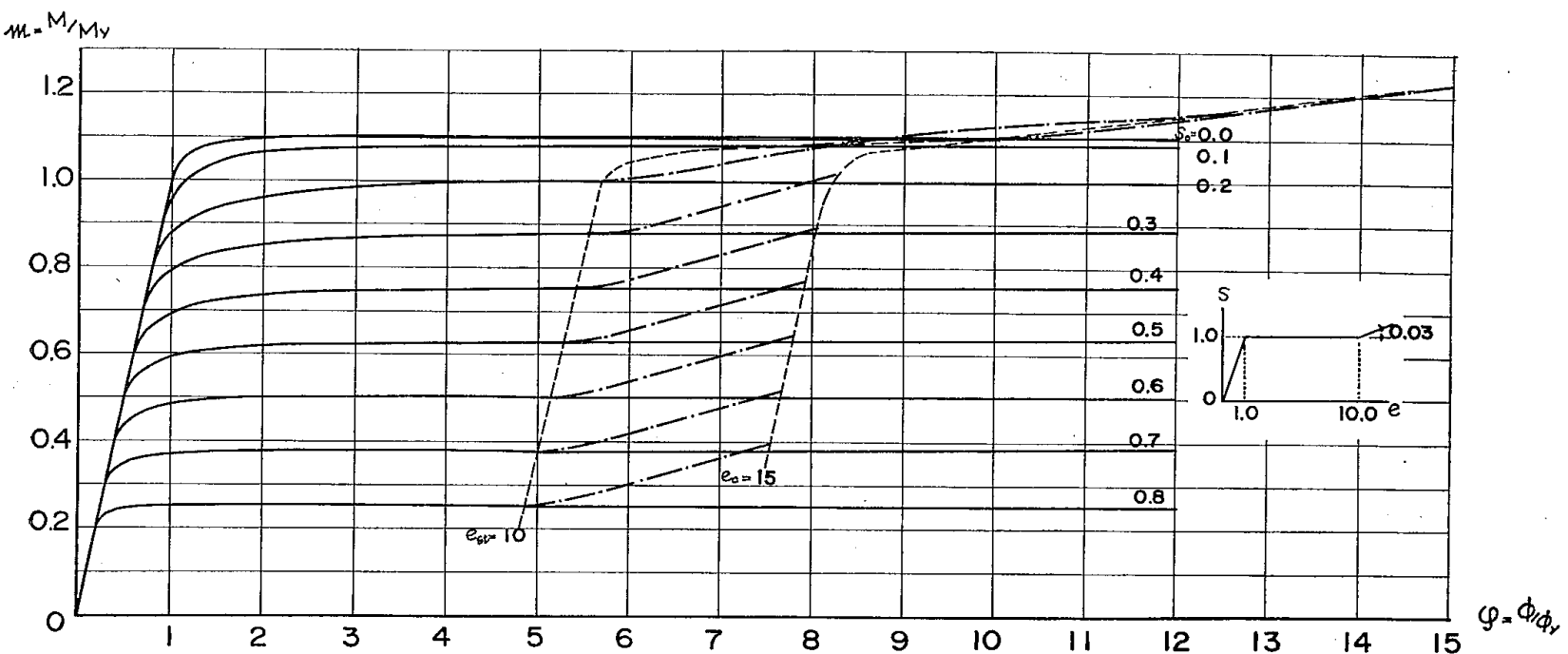

Fig. 2 (a) moment-thrust-curvature relation for $\mathrm{H}$-section

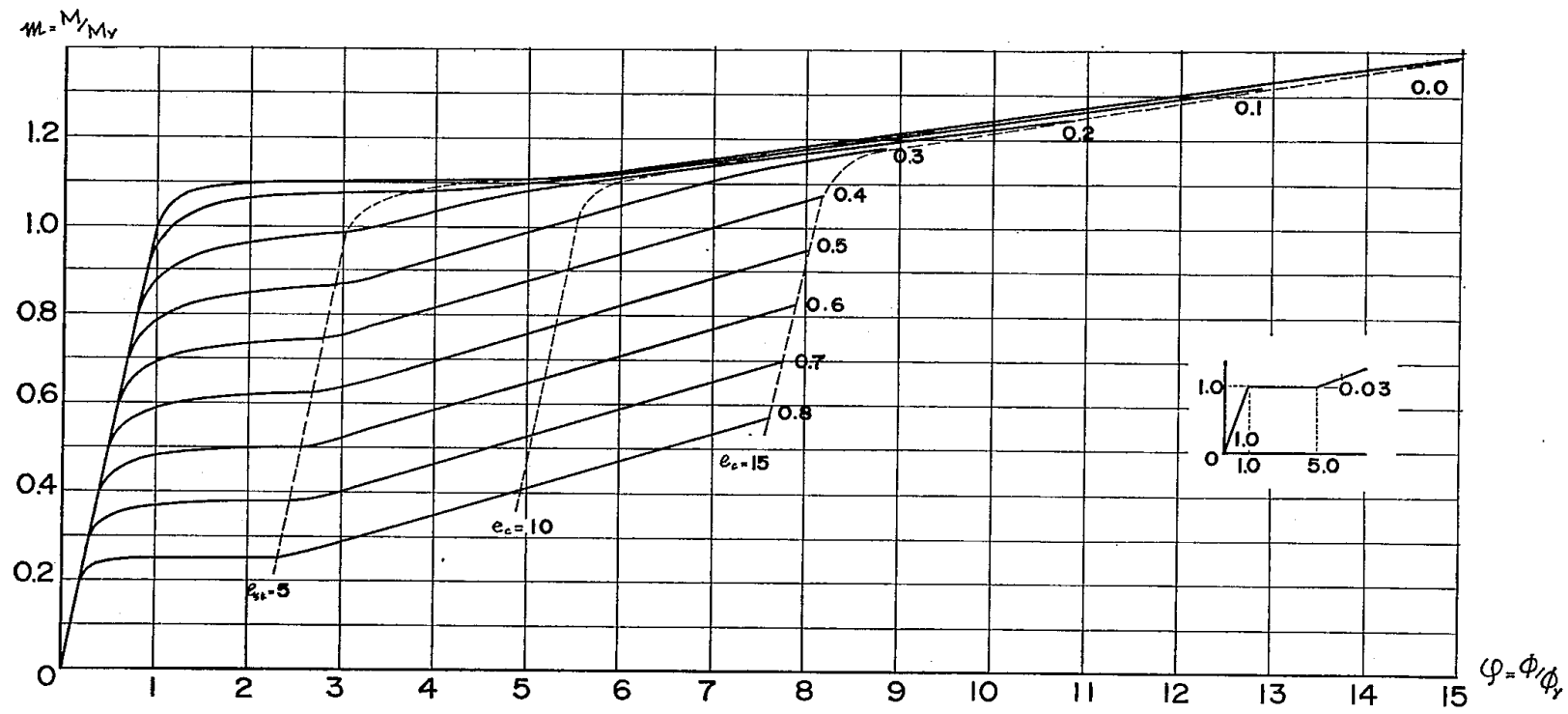

Fig. 2 (b) moment-thrust-curvature relation for $\mathrm{H}$-section

relation と同一の傾向を有すること

がわかる。

Fig. 5 はモーメントー曲率関係を $M / M_{y N}-\phi / \phi_{y N}$ 軸により表現した ものであるが, 図から存在軸力比

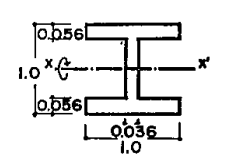

Fig. 3 section dimension $S_{0}=0.2$ を境にして曲線の形状が著しく変わることがわ かる。すなわち，圧緛側フランジ内に中立軸がある場合 には $m-\varphi$ 曲線群はほぼ同一の形状をとり，この範囲 $\left(S_{0} \geq 0.2\right)$ では，存在軸力比 $S_{0}$ に刘空する一群の $m-\varphi$ 曲線は下記の一つの式で表現できる。

$$
\varphi=\phi / \phi_{y}=\left(1-S_{0}\right)\left[A+\frac{1}{B \frac{m}{1-S_{0}}+C}\right]
$$

但し $S_{0} \geq 0.2$

上式にて $m=M / M_{y}, A, B, C$ 注曲線形状を表わす常 数を表わす。

H形断面の歪硬化域も含めた $m-\varphi$ 曲線の一般性状と して Fig. 2 に示されるよらに存在軸力比 $S_{0} \fallingdotseq 0.2$ を境 にして，換言すれば中立軸がウェブとフランジ境界にく る点を境としてこれより軸力比が小さければ歪硬化開始

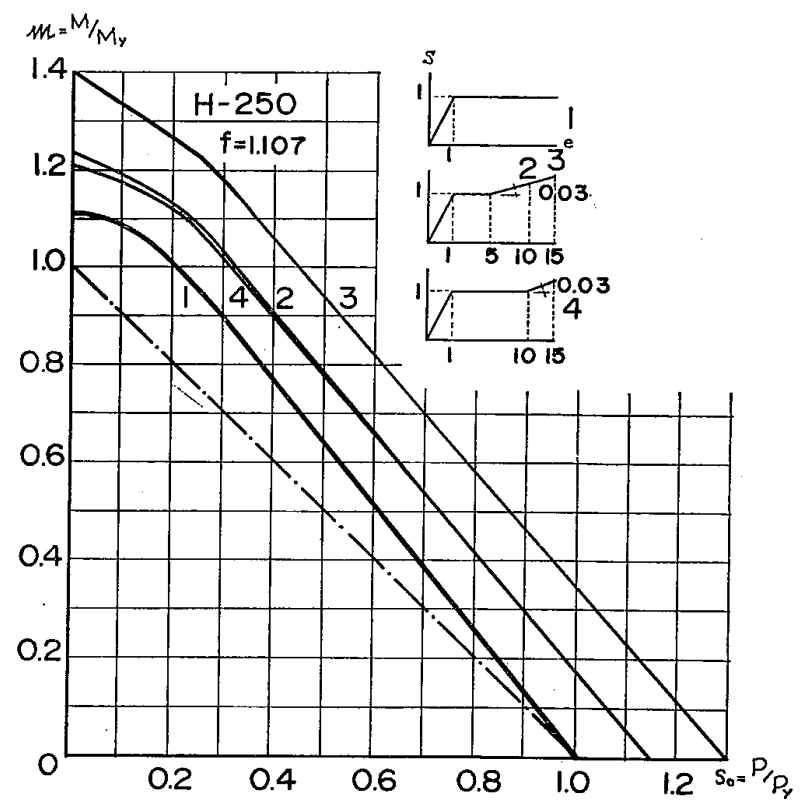

Fig. 4 interaction relation が著しく遅れ，逆に軸力比がこれより大きくなれば硬化 の現われ方が早くなる。

$2.2 m-\beta$ 關数 


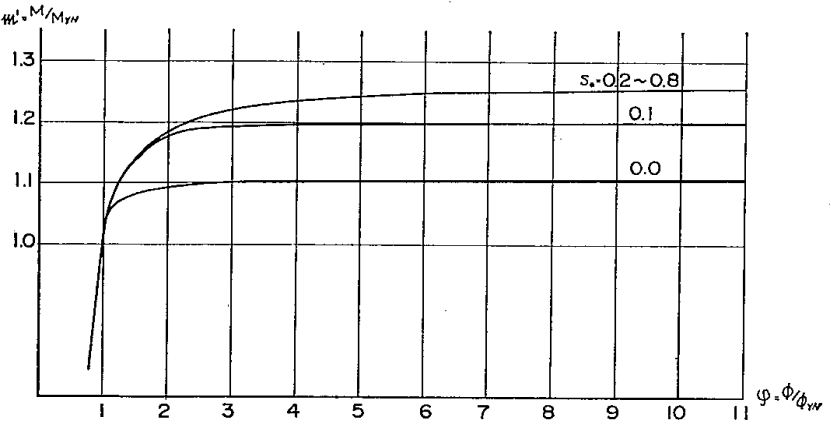

Fig. $5 \mathrm{M} / \mathrm{M}_{y N^{-}} \phi / \phi_{y N}$ relation

既に筆者等が示した弾塑性架構の解析法に用いる塑性 低下係数 $\beta$ を上記 $m-\varphi$ 曲線から求め, 歪硬化域を含め た $m-\beta$ 関数を示したのが Fig. 6 である。応力度一歪度 関係にて歪硬化開始点が各及 $e_{S t}=5.0,10.0$ の場合が 記入されており，限界歪度 $e_{c}=15.0$ に対応する点も示 されている。この $m-\beta$ 関数を用いて解析を行ならこと になるが，後節で示されるように略近解法あるいは耐力 式の誘導に用いる目的でこれ等の $m-\beta$ 関数の線形近似 化を考える。歪硬化現象のない場合には既に架構の安定 限界耐力の解析で述べたよらに文,

$$
\begin{aligned}
\beta & =-\frac{m}{\left(1-S_{0}\right)(1.18 f-1)}+\frac{1.18 f}{1.18 f-1} \\
& =-\frac{\Delta m}{1.18 f-1}+1.0 \quad S_{0} \geq 0.2 \ldots \ldots
\end{aligned}
$$

なる $m-\beta$ 線形近似関数が導かれる。ここに， $f:$ shape factor, $\Delta m=\Delta M / M_{y N}$ を表わし, $\Delta m$ 注降伏モーメン トと以後のモーメント増分との比を示す。H形断面のよ うに shape factor が小さく, $m-\beta$ 曲線が比較的直線に 近い場合には上記 (2.2) 式の与える線形近似化式は後述 の精算による耐力との比較からもわかるように解析の結 果にさほど重要な影響をおよぼさないと考えられる。

歪硬化域においても同溙な線形近似化が可能であると 寸ると, 歪硬化開始点 $\left(m_{S} t, \beta_{S t}\right)$ と限界歪度 $e_{c}=15.0$ となる点 $\left(\bar{m}_{S t}, \bar{\beta}_{S} t\right)$ を結ぶ直線は，

$$
\begin{aligned}
\beta & =-C\left(m-m_{S t}\right)+\beta_{S t} \\
& =-a \Delta m+b \\
a & =C\left(1-S_{0}\right), b=C\left(1-S_{0}\right)(1.18 f-1)\left(1-\beta_{S t}\right)+\beta_{S t}
\end{aligned}
$$

上式にてCは直線の勾配を表わし，Fig. 7 a）に描吕 れるように存在軸力比 $S_{0}$ によって変わる曲線となる。 Fig. $7 \mathrm{~b}$ ) 㤬歪硬化開始点並びに $e_{c}=15.0$ となる点の

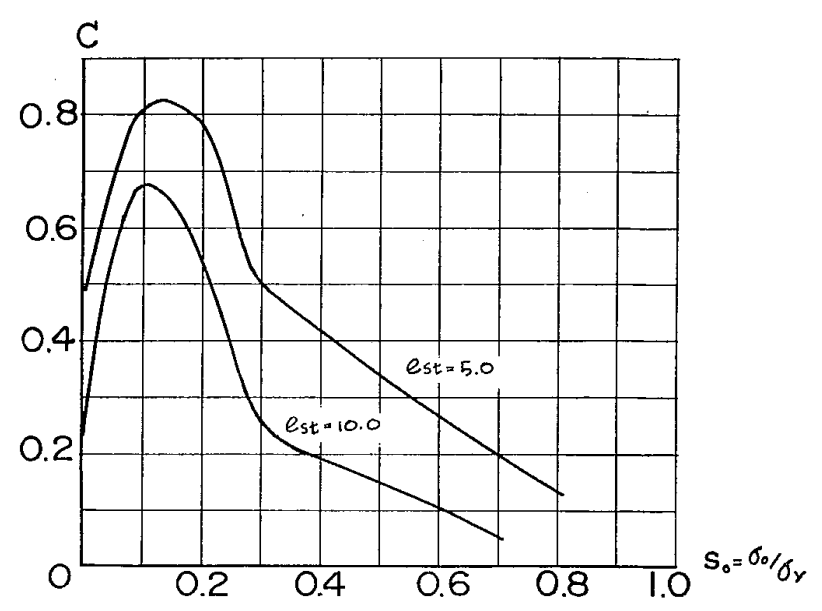

Fig. 7 a) $C-S_{0}$ relation

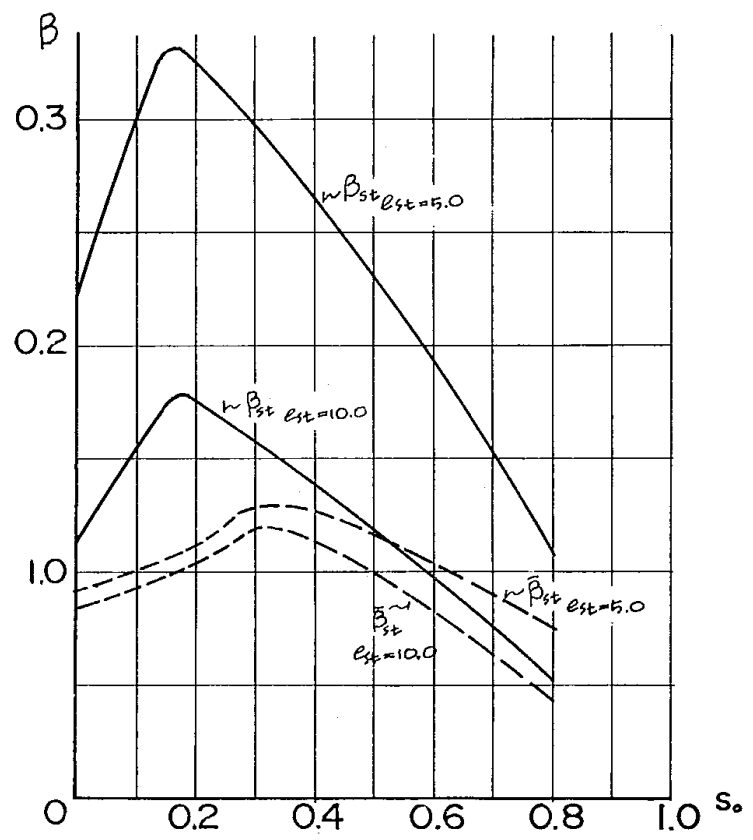

Fig. 7 b) $\beta-S_{0}$ relation

$\beta_{S t}, \bar{\beta}_{S t}$ 值を描いたものであって， $\sigma-\varepsilon$ 特性に拘らずほ ぼ同一の形状を示している。

\section{§3. 単一材における歪硬化現象}

最も簡単な構造系として Fig. 8 に示す cantilever beam-column における歪硬化現象について検討する。

3.1 cantilever bam-column の解析

Fig. 8 に示す cantilever berm-column が一定軸力 $P$, 漸増水平力 $q P$ を受ける場合の弾塑性解析について

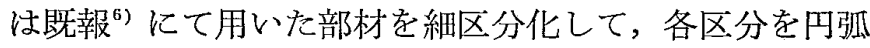

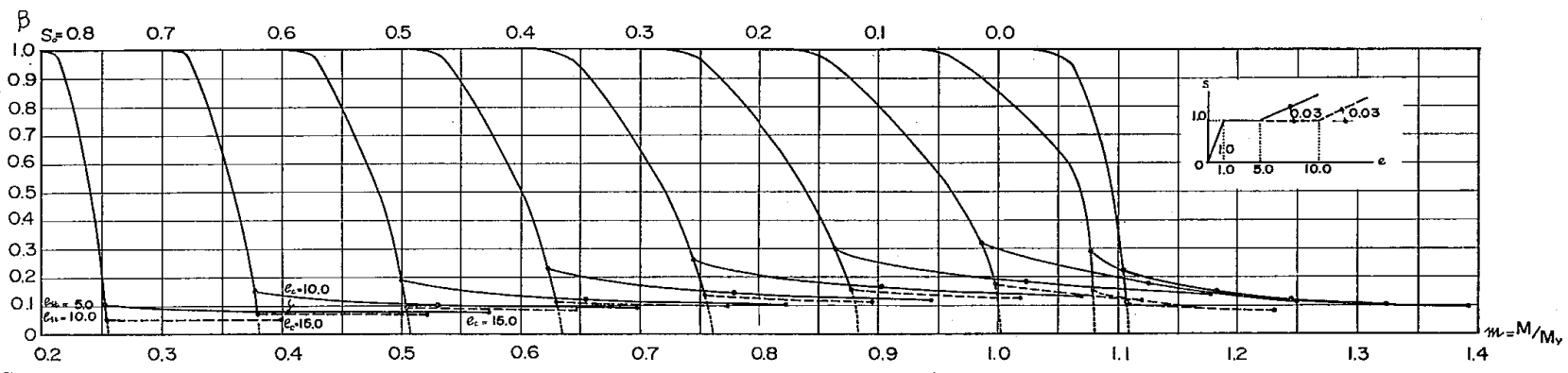

Fig. $6 n-\beta$ relation 
と仮定し，各区分点に扔けるモ一 メント並びに曲摔を求め, 与変形 $\delta$ に刘応する水平力係数 $q$ を見 出す手法を用いる。

Fig. 9 は解析結果 $の$ 数例を示 したものである。これらの変形曲 線に招ける歪硬化現象の現われ方 は次のように大別される。

i ）歪硬化を考慮しない場合 の安定限界耐力に達する以前に歪 硬化現象が始まり歪硬化域で不安定現象を示し, 以後耐 力が減少する場合 (Type 1)

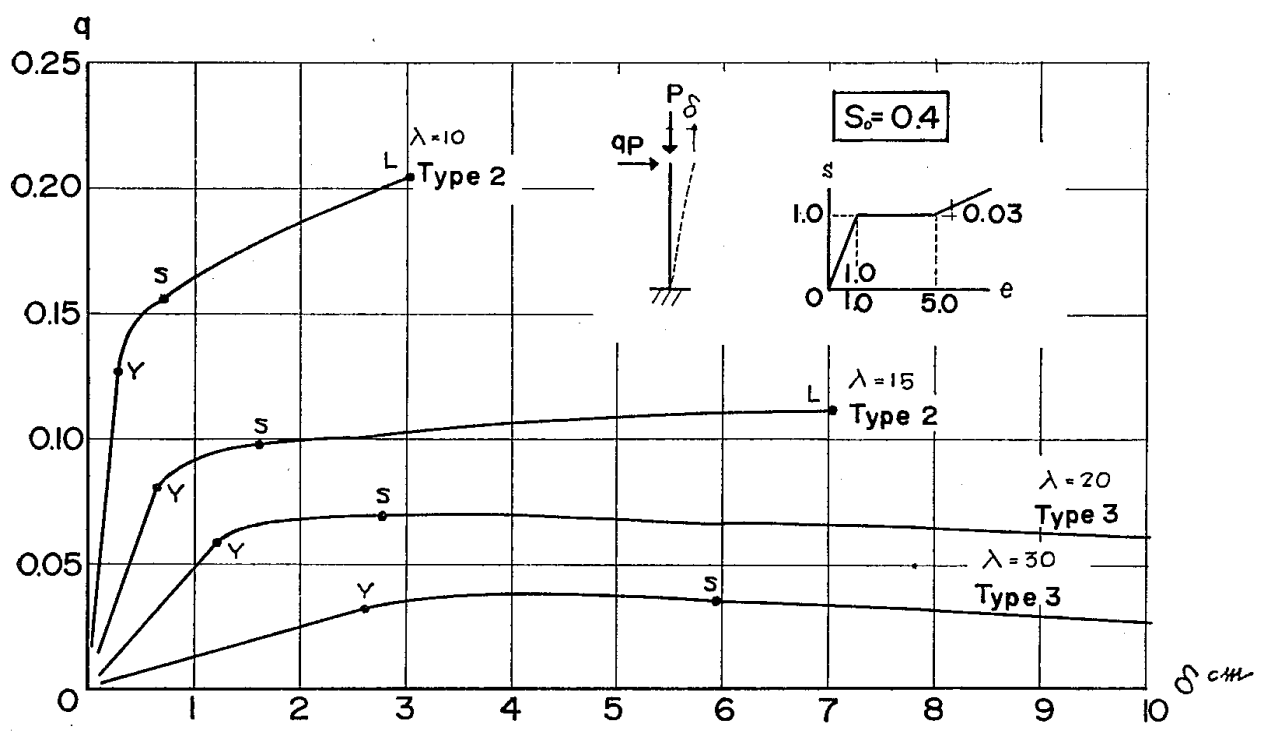

Fig. 9 a) load-deflection relation

\section{q}

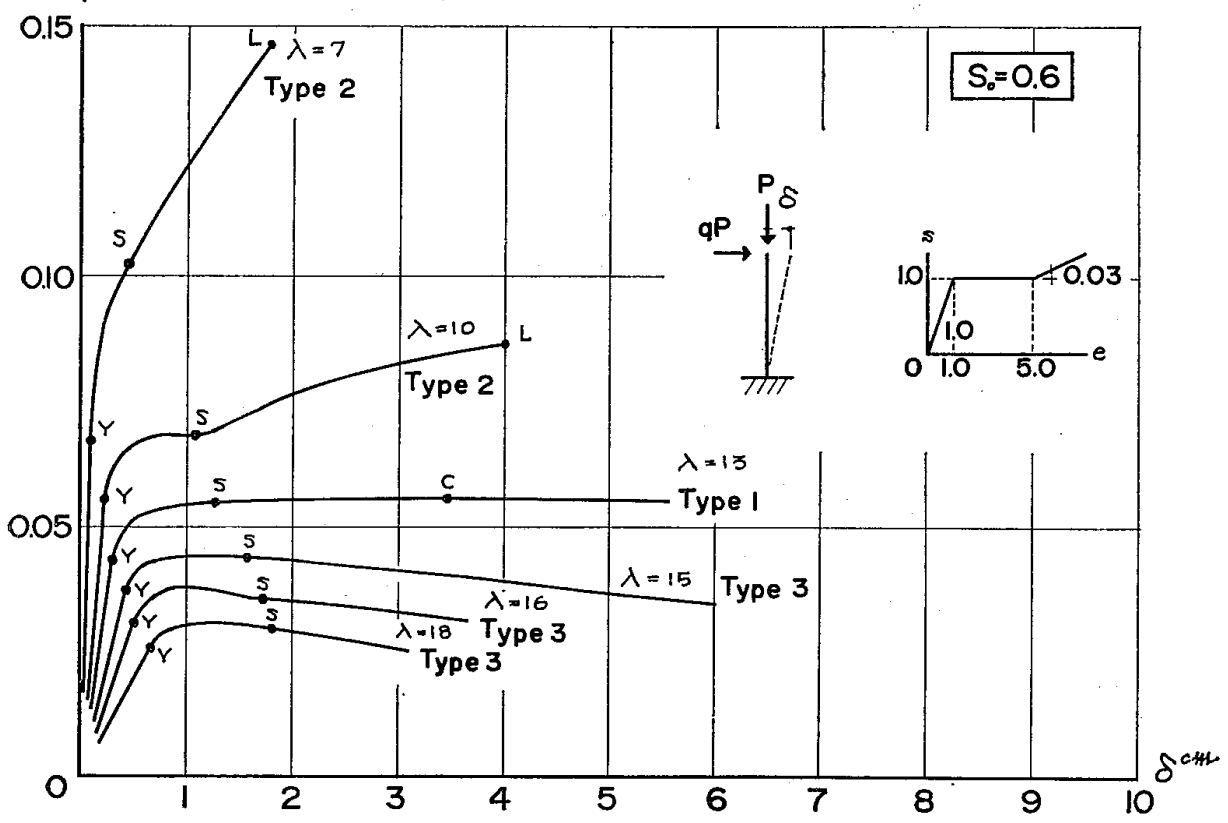

Fig. 9 b) load-deflection relation point $Y$ : initial yielding point $S$ : begining of strain-hardening point $C$ : instability point point $L$ : local buckling, $e_{c}=15 \varepsilon_{y}$

Fig. 9 load-deflection relation ii）歪硬化域で安定限界に到する前に断面の圧縮側 フランジ歪度が限界歪度 $e_{c}=15.0$ に達し局部不安定現 象により最大耐力が規定される場合 (Type 2)

iii）歪硬化の影響の 現われるのが遅く，安定限界に 達し荷重一変形曲線が一時降下し, その 後再び 耐力の上 昇を見る場合 (Type 3)

構造系の安定性あるいは安全性の見地加ら iii）の場合 は健全な応答といい難いので歪硬化現象が構造系に有効 な効果をもたらすものとして i)，ii）の場合を以下の考 察の対象とする。

\section{2 歪硬化を考慮しない場合}

Fig. 8 に示した cantilever beam-column の耐力式 を塑性低下係数 $\beta$ を用いて既報 で示した手法で導いてみよう。 弾性域では*,

$$
\begin{aligned}
& \delta=\frac{q l}{\frac{3 E I}{P l^{2}}-1} \cdots \\
& M=\frac{q P l}{1-\frac{P l^{2}}{3 E I}} \cdots
\end{aligned}
$$

弾塑性域で注下係数 $\beta$ を用 いて各值の降伏後の増分に対し て次式が成立つ。

$$
\begin{gathered}
\Delta \delta=\frac{\Delta q l}{\frac{3}{(k l)^{2}} \beta-1} \cdots \\
\Delta M=\frac{\Delta q P l}{1-\frac{(k l)^{2}}{3} \frac{1}{\beta}} \cdots
\end{gathered}
$$

$K=3 /(k l)^{2}, \quad \Delta d=\Delta \delta / \delta_{y} \quad$ とお き，下式の如く無次元化する。

$$
\begin{gathered}
\Delta Q=\Delta q / q_{y}=\frac{K \beta-1}{K-1} \Delta d \\
\ldots \ldots \ldots \ldots \cdots \cdots(3.5) \\
\Delta m=\Delta M / M_{y N}=\beta \Delta d
\end{gathered}
$$

さらに前記線形近似化 $m-\beta$ 関 数完,

$$
\beta=-a \Delta m+b \cdots(3.7)
$$

の如く表現して和く。安定限界 耐力は (3.6)，(3.7) 式を満足 する (3.5) 式の極值を求める問 題となる。簡単な計算の後次式 以下が得られる。

$$
\beta_{c r}=\sqrt{b / K}
$$

\footnotetext{
* $(k l)^{2}=P l^{2} / E I=\sigma_{y} / E \cdot S_{0} \lambda^{2}$ とすれ ば $(k l)^{2}<2.5\left(\lambda \leq 50, S_{0} \leq 0.7\right) の$ 範国で注精算值に対して $3 \sim 5 \%$ の誤差となる。
} 


$$
\begin{aligned}
& (\Delta d)_{c r}=\frac{\sqrt{b K-1}}{a} \\
& (\Delta Q)_{c r}=\frac{(\sqrt{b K}-1)^{2}}{a(K-1)}
\end{aligned}
$$

従って暁み，安定限界耐力に関する全量は，

$$
\begin{aligned}
& d_{c r}=1+(\Delta d)_{c r}=1+\frac{\sqrt{b K}-1}{a} \ldots \ldots \\
& Q_{c r}=1+(\Delta Q)_{c r}=1+\frac{(\sqrt{b K}-1)^{2}}{a(K-1)}
\end{aligned}
$$

上式にて (2.2)式に表現されるように $a=1 /(1.18 f-1)$, $b=1$ を代入すれば安定限界耐力係数 $q_{c r}$ は,

$q_{y}=\frac{M_{y N}}{P l}\left(1-\frac{1}{K}\right):$ 初期降伏時耐力倸数

$q_{R}=\frac{M_{p N}}{P l}$ : rigid plastic theory $の$ 与える耐力 係数

を用いて次の如く縓めることができる。

$$
\begin{aligned}
q_{c r} / q_{R} & =\left(1+\Delta q_{c r} / q_{y}\right) \frac{q_{y}}{q_{R}} \\
& =1 \frac{2(1.18 f-1)}{1.18 f} \sqrt{1 / K}-\frac{2-1.18 f}{1.18 f}(1 / K) \\
& =1-\frac{2(1.18 f-1)}{1.18 f} \sqrt{P / P_{c r}}-\frac{2-1.18 f}{1.18 f} \\
\left(P / P_{c r}\right) \cdots \cdots(3.13) &
\end{aligned}
$$

上式にて $P_{c r}$ は lowest elastic buckling load を表わ す。 shape factor $f=1.107$ を代入すれば,

$$
q_{c r} / q_{R}=1.0-0.46 \sqrt{P / P_{c r}}-0.54\left(P / P_{c r}\right)
$$

既に W. Merchant が指摘したように部材あるいは 架構の弾塑性安定限界耐力は rigid plastic theory の 与える耐力並びに lowest elastic buckling load との
閒に次の如きいわゆる Rankine formula の関係をむ D。

$$
q_{c r} / q_{R}=1.0-P / P_{c r}
$$

(3.13) 式にて $q_{c r} / q_{R}=1.0-K_{2} \sqrt{P / P_{c r}}-K_{1}\left(P / P_{c r}\right)$ の形に緾めれば， $K_{1}+K_{2}=1.0$ であって $K_{1}, K_{2}$ は部 材の断面形状, 支持条件により変化する parameter と いえ, shape factor $f=1.0$ の時に恃, $K_{1}=1.0, K_{2}=0$ となり上記 Rankine formula に対忘する。

矩形断面にあっては shape factor $f=1.5$ であり, H形断面よりもかなり大きい。この矩形断面部材の耐力 式を導くため, 矩形断面の $m-\beta$ 関数を棈可にて近似さ せる。

$$
\beta=\sqrt{1.0-(\bar{a} \Delta m)^{2}}
$$

上式にて $\bar{a}$ は存在軸力比 $S_{0}$ により変わる parameter であり， $\Delta m=\Delta M / M_{y N}$ である。安定限界耐力係数 $q_{c r}$ は (3.16)，(3.7) 式を满足する (3.5) 式の極值を求め る問題となり，前記と同様に次式が得られる。

$$
\begin{aligned}
q_{c r} / q_{R}= & \frac{1}{1.5 \bar{a}\left(1+S_{0}\right)}\left\{a\left(1-P / P_{c r}\right)\right. \\
& +\left(1-\left(P / P_{c r}\right)^{2 / 3}\right) \sqrt{1-\left(P / P_{c r}{ }^{2 / 3}\right\}}
\end{aligned}
$$

Fig. 10 にこれらの耐力式群を示す。同図からいわゆ る Rankine formula は (3.14) または (3.17) 式の与え る耐力よりもやや高めの值を与学ることが指摘される。 既述（3.1）の手法による rigorous solution の解析結 果も併せ記入されているが，(3.14) あるマは (3.17) 式 の与光安定限界耐力式はこれら解析結果と良く一致し ているといえよう。

H形断面部材に対す而耐力式 (3.14) 式は矩形断面材

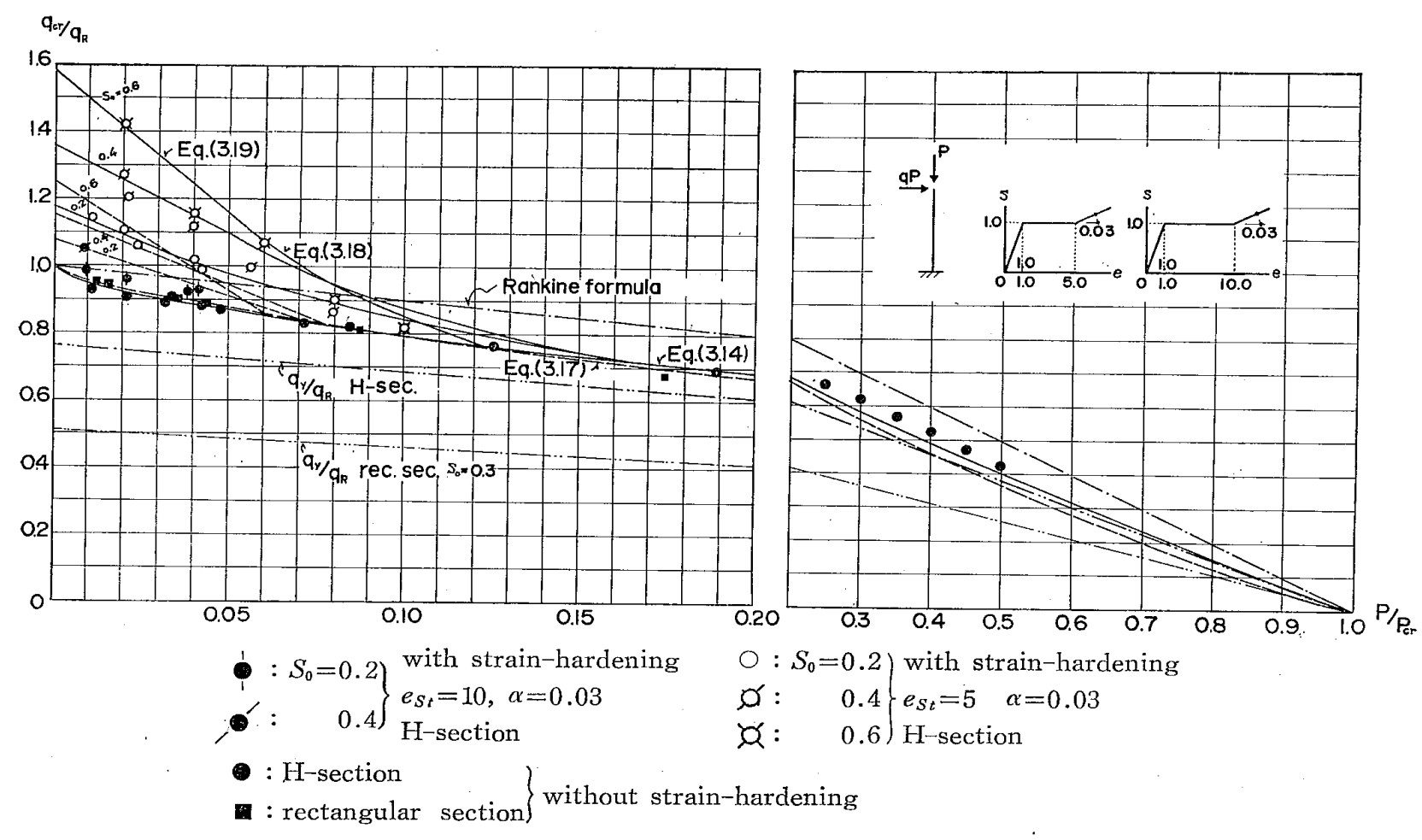

Fig. $10 q_{c r} / q_{R}-P / P_{c r}$ relation for cantilever beam-column 
に対する (3.17) 式よりやや高目の值を与えるが， $P / P_{c r}>0.2$ ではこの差がより明膫となり部材断面形状 による耐力の差が現われている。

ii）歪硬化域を考慮した場合

前述のように歪硬化域において最大耐力に達する場合 はいわゆる系全体が安定限界耐力を示す場合と耐力曲線 が未だ上昇するにも拘らず局部不安定現象による限界歪 度で耐力が決まる場合に分けられる。

前者にあっては線形近似化 $m-\beta$ 関数を用いて前項と 全く同様に耐力を求めることができる。すなおち(3.12) 式上り安定限界耐力式は, 次のように䌂められる。

$$
\begin{aligned}
q_{c r} / q_{R}= & \frac{1}{1.18 f}\left\{\left(1+\frac{b}{a}\right)-\frac{2 \sqrt{b}}{a} \sqrt{1 / K}\right. \\
& \left.-\left(1-\frac{1}{a}\right)(1 / K)\right\} \\
& \fallingdotseq \frac{1}{1.18 f}\left\{\left(1+\frac{b}{a}\right)-\frac{2 \sqrt{b}}{a} \sqrt{P / \overline{P_{c r}}}\right. \\
& \left.-\left(1-\frac{1}{a}\right)\left(P / P_{c r}\right)\right\} \cdots \cdots \cdots \cdots \cdots(3 . \cdots \cdots \cdots \cdots
\end{aligned}
$$

上式にて $a, b$ は (2.3) 式の值をとる。

局部不安定現象にて耐力が決まる後者の場合は限界歪 度 $e_{c}=15.0$ の時の $\bar{\beta}_{S t}$ 一值を用いて (3.6) 式より,

$$
\Delta m=\frac{1}{a}\left(b-\bar{\beta}_{S t}\right)=\bar{\beta}_{S t} \Delta d \quad \therefore \Delta d=\frac{1}{a \bar{\beta}_{S t}}\left(b-\bar{\beta}_{S t}\right)
$$

を得る。これを(3.5) 式に代入すれば，次の上らな耐力 式を得る。

$$
\begin{aligned}
q_{c r} / q_{R}= & \frac{1}{1.18 f}\left\{\left(1+\frac{b-\bar{\beta}_{S t}}{a}\right)\right. \\
& \left.-\left(1+\frac{b-\beta_{S t}}{a \beta_{S t}}\right)(1 / K)\right\} \\
& \fallingdotseq \frac{1}{1.18 f}\left\{\left(1+\frac{b-\beta_{S t}}{a}\right)\right. \\
& \left.-\left(1+\frac{b-\beta_{S t}}{a \beta_{S t}}\right)\left(P / P_{c r}\right)\right\}
\end{aligned}
$$

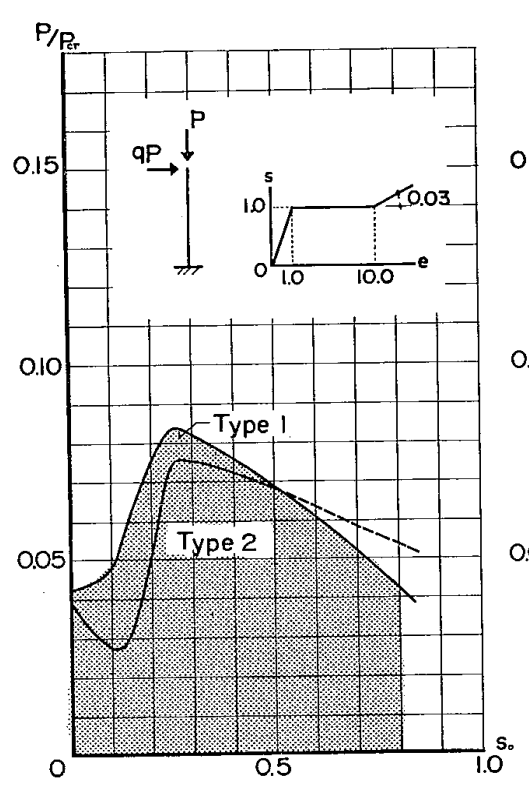

(a)

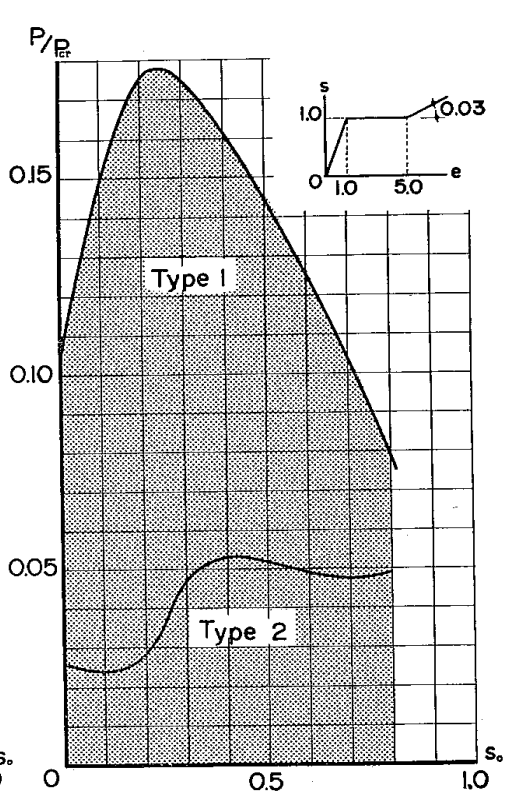

(b)
Fig. 11 effective zone of strain-hardeming
上式の $a, b$ には (2.3) 式の值が当てられる。これら $a$ ， $b, \beta_{S t}$ は断面形状, $\sigma-\varepsilon$ 特性並びに存在軸力比 $S_{0}$ によ って変る parameter である。従って耐力むまたこれら の諸因子によって影響されることとなる。

Fig. 10 に以上の各場合に対する耐力式 (3.18), (3.19)式を図示する。すなわち， $\sigma-\varepsilon$ 特性として Fig. 1 の二種を選び, 存在軸力比 $S_{0}=0.2,0.4,0.6$ について 描いたものであって, 同図には精算による解析結果も plotされている。

ここで耐力式 (3.18)，(3.19）式の成立する範囲につ いて調べる。(3.18) 式の成立する $P / P_{c r}$ 一值の限度は (3.13)，(3.18)式を等置して整理すれば次の方程式の根 となる。

$$
\begin{aligned}
& \left(1.18 f-1-\frac{1}{a}\right) P / P_{c r}+2\left(\frac{\sqrt{b}}{a}-1+1.18 f\right) \sqrt{P / P_{c r}} \\
& +\left(1.18 f-1-\frac{b}{a}\right)=0 \text {. }
\end{aligned}
$$

上式にて $a, b$ は (2.3) 式の值をとる。

また (3.19) 式の成立限界は (3.18), (3.19) 式を等 置して整理すれば,

$$
P / P_{c r}=\beta_{S t}{ }^{2} / b
$$

ここに $b$ は (2.3) 式の值をとる。物理的意味から当然 (3.20) 式の与える $P / P_{c r}$ 一值よりも (3.21) 式のそれの 方が小さいことは明らかである。従って (3.20) 式の. $P / P_{c r}$ 一值よりも大きい範囲では歪硬化が耐力に有效な 効果をもたらさず，(3.21）式の与える值よりも大きい $P / P_{c r}$ 一值に対しては安定限界耐力を示す (3.18) 式で耐 力が決まり，この值よりも小さい $P / P_{\text {cr }}$ 一值にあっては 局部不安定現象で耐力が決まる (3.19) 式が用いられる こととなる。これらの範囲を示したのが Fig. 11 で女 る。

以上の事柄から次の考察を加えることができる。

(i) 歪硬化域に打ける耐力式 (3.18), (3.19). 式は精算による解析結果とほぼ一致する。

(ii) 歪硬化が有効となるためには， $P / P_{c r}$ 値が Fig. 11 に示すような範囲にあることが必 要であり,この時限界耐力は荷重一変形曲線がい わゆる安定限界点を示寸場合 (Type 1) と耐力が 上㫒するにも拘らず圧縮側フランジ歪度が局部不 安定現象による限界歪度に達して耐力が決まる場 合 (Type 2) に分けられる。

(iii) $\sigma-\varepsilon$ 特性に拘らず存在軸力比 $S_{0} \fallingdotseq 0.2$ 程 度で歪硬化が最む有効に働くが $e_{S t}=5.0$ の場合 に較べ $\sigma-\varepsilon$ 曲線の踊り場長さの長い $e_{S t}=10.0$ の場合は $P / P_{c r}$ 一值の有効籁囲が著しく減ずる。

(iv) Wずれの場合む $P / P_{c r}$ 一值が比較的小さ 、範囲では $P / P_{c r}$ 一值一定の条件下において存在 軸力比 $S_{0}$ が大きいほど $q_{c r} / q_{R}$ 一值は大きい值を とり耐力曲線は勾配がより急となる。 
(v) 耐力曲線が縦軸 $\left(q_{c r} / q_{R}\right.$-軸) を截る点は $e_{c}=$ 15.0 の時のモーメント $M_{p s}$ をもつよらな剛塑性系の 限界耐力を示す点である。

(vi) $e_{S t}=10.0 \cdot$ 場合では踊り場長さの短い $e_{S t}=$ 5.0 に較べて耐力は凡そ $1 / 2$ 以下に低下し，前者の場合 には後者の場合ほど歪硬化が有効な効果をもたらさな w。

iii) 靯性率について

構造系の靯性率（ductility factor）を限界耐力時の変 形量と初期降伏時のそれとの比 $\mu=\delta_{c r} / \delta_{y}$ で規定すれ ば，上述の場合における勒性率は次のよらになる。 歪硬化を考慮しない場合：

$(2.2),(3.11)$ 式より,

$$
\begin{gathered}
\mu=1+(\Delta d)_{c r}=2.0-1.18 f+(1.18 f-1) \sqrt{K} \\
\quad \fallingdotseq 2.0-1.18 f+(1.18 f-1) \sqrt{P_{c r} / \bar{P}}
\end{gathered}
$$

上式に shape factor $f=1.107$ を代大すれば,

$$
\mu \fallingdotseq 0.7+0.3 \sqrt{P_{c r} / P}
$$

歪硬化域を考慮した場合：

限界耐力がいわゆる安定限界点で決まる場合には (2.3)，(3.11) 式より，

$$
\mu=\left(1-\frac{1}{a}\right)+\frac{\sqrt{b}}{a} \sqrt{K} \fallingdotseq\left(1-\frac{1}{a}\right)+\frac{\sqrt{b}}{a} \sqrt{P_{c r} / P}
$$

また，局部不安定現象により耐力が決まる場合には限界

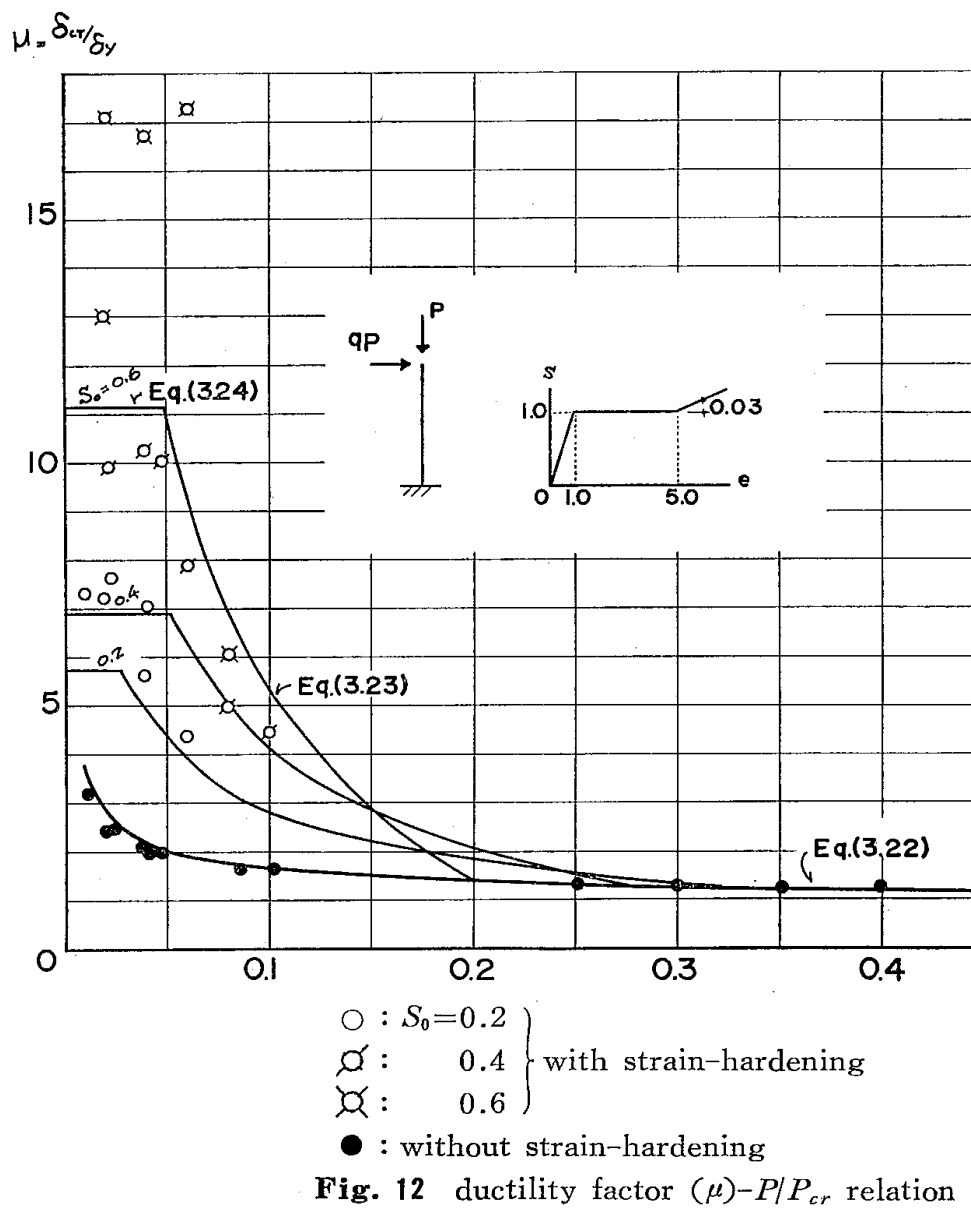

歪度 $e_{c}=15.0$ の時の $\beta_{S t}$ 一值を用いて，(2.3)，(3.6) 式より $\Delta m$ を消せば,

$$
\mu=1+(\Delta d) \bar{\beta}_{S t}=1+\frac{1}{a \bar{\beta}_{S t}}\left(b-\bar{\beta}_{S t}\right)
$$

(3.23)，(3.24) 式における $a, b$ は (2.3) 式の值を とる。以上の $\mu-P / P_{c r}$ 関係を描いたものが Fig. 12 で あって，精算による解析結果も記入されている。同図に て，歪硬化域については $e_{S t}=5.0$ の場合を採ってい る。同図加ら歪硬化学考慮しない場合の $\mu-P / P_{c r}$ 関係 は精算による解析結果とよく一致しており， $P / P_{c r}$ 一值 が小さい值であれば勒性率も高いが，逆に $P / P_{c r}$ 一值が 大きくなれば勒性率む漸次低下する様子が理解できる。

歪硬化域を考慮した場合の䩲性率を与光 (3.23)， (3.24) 式は解析結果と同一傾向 を有するが，局部不安 定現象で変形限界が決まる範囲では，解析結果はいずれ も (3.24) 式より高い値となっている*。局部不安定現象 が限界変形量を規定する (3.24) 式汇 $\sigma-\varepsilon$ 特性, 存在軸 力比 $S_{0}$ が一定であれば $P / P_{c r}$ 一值に拘らず靸性率は一 定となることを示しているが解析結果でもほぼ一定の值 をとっていることは興味深い。いずれの場合も $P / P_{c r}$ 值が増せ愺勒性率は急激に低下しており歪硬化による靭 性率の増加が期待できる範囲 は余り大きくないといえ る。

\section{§4. portal frame の解析}

Fig. 13 に示すような柱脚固定 portal frame が柱頭 に一定軸力 $P$ 並びに漸増水平 力 $2 q P$ 学受け, panel type $の$ collapse mode をとる場合の歪 硬化域における挙動について应

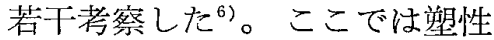
低下係数 $\beta$ 学用いる略近的解析 により歪硬化現象がこのような portal frame の耐力並びに変 形性状におよぼす効果について 述べる。

\section{1 安定限界耐力}

既報のように歪硬化域におけ る荷重一変形曲線は断面の $m-\beta$. 関数を用いて略近的に追跡でき る。Fig. 14 は京大若林教授に よって行なわれた実験結果 7 *** と解析曲線を比較したものであ り, 載荷初期の弾性部分を除い て実験結果と解析曲線は同一性

*この原因の一つに略近解析によ る䛊差が挙げら㞦る。

** 材質 SS 41, 断面 H-100 × 100× $8 \times 6$ よりなる $100 \times 100 \mathrm{~cm}$ の 中形試験体。 


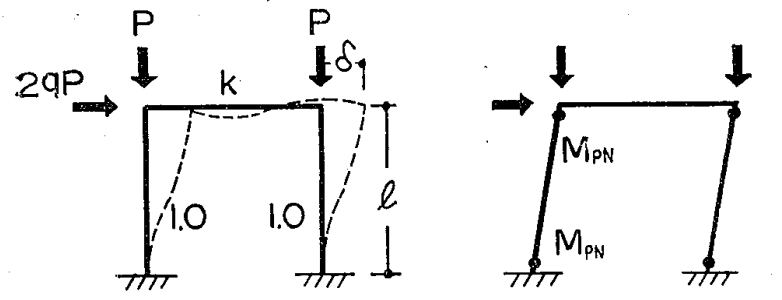

Fig. 13 portal frame

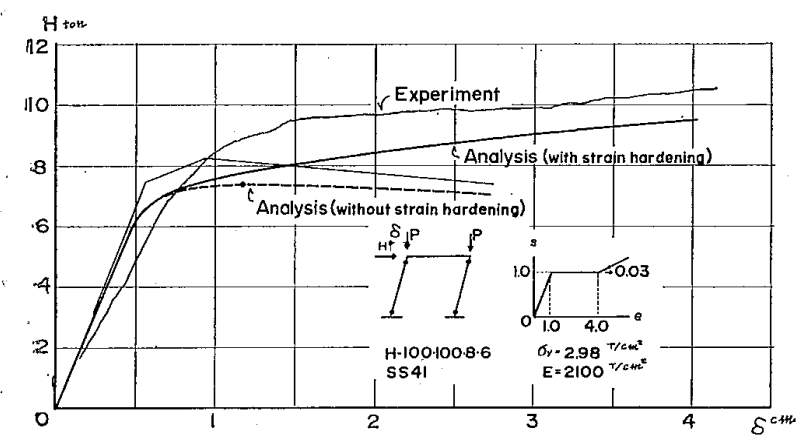

Fig. 14 a) load-deflection relation of portal frame

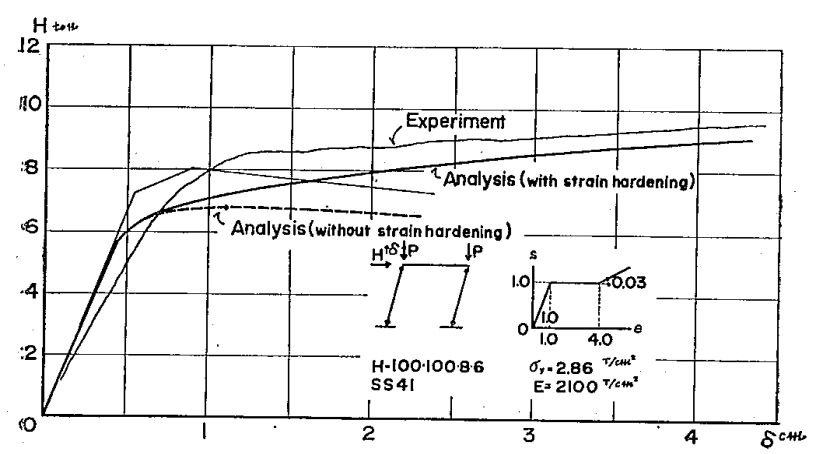

Fig. $14 \mathrm{~b}$ ) load-deflection relation of portal frame
状を有している。いずれの場合も荷重一変形曲線は軸力 が存在するにも拘らず歪硬化現象によって漸次耐力が增 大する傾向にある。

このような portal frame の弾・塑性不安定現象に影 響をおよぼすものとして，frameの断面形状に関する諸 元, 存在軸力比 $S_{0}$ 並びに材料の $\sigma-\varepsilon$ 特性を挙げること ができる。また，簡単な構造系の例として cantilever beam-column の解析に示されたように系の挙動を簡単 化して導かれる 2 つの耐力すなわち系の挙動をあくまで 弾性と見做した時の lowest elastic buckling load 並 びに幾何学的位置変化を考慮しない，いわゆる rigid plastic theory の与える崩壊荷重との間には (3.16) 式 の関係が認められる。このような関係は更に複雑化し た構造系である架構の場合にも応用できるであるう。 frame の歪硬化域による耐力の高まりに対しても前節 で考察したよらな関連性すなわち材料の $\sigma-\varepsilon$ 特性（踊り 場長さ並びに歪硬化域の立上り勾配), 存在軸力比 $S_{0}$ が 極めて大なる影響を与えることが予測される。このよう な安定限界耐力の高まりに対しても前節の cantilever beam-column の場合と同㥞に荷重一変形曲線でいわ㘦る 安定限界点を示し，以後耐力曲線 が漸次低下するもの と，圧縮側フランジの歪度が限界歪度に達して最大耐力 に到る 2 つの場合に分けることができよう。Fig. 15 は $e_{S t}=5.0, \alpha=0.03$ (Fig. $1 \mathrm{~b}$ ), 存在軸力比 $S_{0}=0.2$, $0.4,0.6$, はり岡比 $k_{b}=0.5 \sim 2.0$, 柱細長比 $\lambda=15 \sim 70$ を想定した場合の解析結果である。同図には歪硬化域を 考慮しない場合も併せ記入されてい る。同図加ら cantilever beam-column の場合と同様な傾向を認める ことができる。すなわち，柱軸力 が小さいほぼまた lowest elastic buckling load が大きい架構ほざ歪 硬化域による耐力の高まりが期待で き, $P / P_{c r}$ 一值一定の 条件下で惊存 在軸力比 $S_{0}$ が大きい注ど $q_{c r} / q_{R}-$ 值滈い值となる。また，存在軸力 比 $S_{0}$ が小さいほど歪硬化の期待で きる範囲が大きくなる。このように 歪硬化域の効果が存在軸力比 $S_{0}$ に よって大きく変わること㤬実際的立 場からの歪硬化現象の正当な評価を 困難にするものと考えられる。

\section{2 勒性率}

Fig. 16 は上記 portal frame の 勒性率 $\mu$ と $P / P_{c r}$ 一值の関係を。 歪硬化域を考慮する場合としない場 合について図示したものであり，後 者に比し前者の場合は勒性率が著し 
く増大する状沉が理解できる。 また, 存在軸力比によって硬化 域に打ける靸性率が大きく変わ ることも認められる。さらに， 勒性率はいずれの場合も $P / P_{c r}$ 一值の増大に伴って急激に低下 することが指摘される。

\section{§5.結、語}

歪硬化域が構造系の耐力ある 、注変形性状におよぼす效果は 存在軸力比 $S_{0}$, 構造系の断面形 状に関する諸值並びに材料の $\sigma-\varepsilon$ 特性によって異なりこれら の影響を一義的に論ずることは 甚だ難しい問題さい方よう。

本稿では基本的な構造系を対 象にこれらの事柄に関する基礎 的な考察を行なった，すなわち rigid plastic theory の与える 崩壊荷重並びに lowest elastic buckling load c弹塑性安定限 界耐力との関連性括よび勒性率 こ $P / P_{c r}$ 一值の関係を主として 論じた。

このような鋼構造物における歪硬化現象の諸効果をさ らに的確に解明するためには，

(i) 鋼材の定量的 $\sigma-\varepsilon$ 特性

(ii）残留応力度が分布する部材あるいは架構におる る歪硬化現象の現われ方

（iii）不静定次数の高い構造系換言すれば降伏の発生 点が多く構造系の降伏並びに歪硬化現象が漸次進展する 上うな場合の挙動

(iv） 局部座屈現象と耐力限界との関連 等の問題に関するより精確な知識を必要とする。いずれ にせよ，少なくとも筆者等が取上げた仮説 $(\sigma-\varepsilon$ 特性, 局部座属による限界歪度等) 並びに構造系では $P / P_{c r}<$ $0.1 \sim 0.2$ の範囲外では 従来からの歪硬化に対するや〉

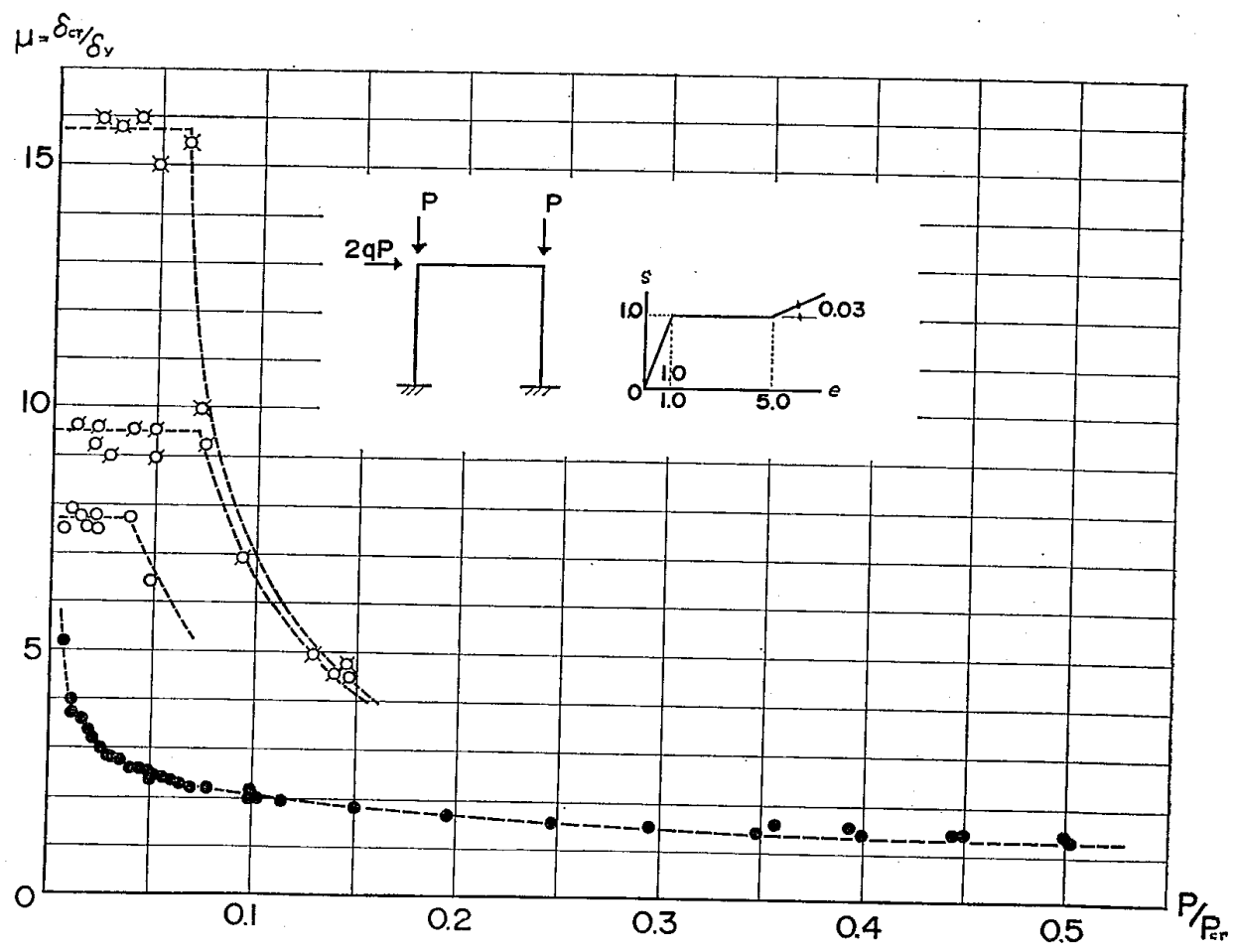

$0: S_{0}=0.2$

$\varnothing: 0.4\}$ with strain-hardening

os: 0.6

- : without strain-hardening

Fig. 16 ductility factor $(\mu)-P / P_{c r}$ relation

もすれば積極的な評価は下しえないとみることができ る。

<註並びに引用文献〉

1）八幡ワイドフランジ鋼 Hs-250 (shape factor $f=1.107$ ) に相当する。

2) 横尾, 坂本, 宮村, “組合せ灾力学ける H-形断面の曲 率関数” 学会東海支部研 1965.12

3) Haaijer, G., "Plastic buckling in the strain-hardening range" Proc. of ASCE, EM 2, April, 1957

4）加藤, “面内圧縮学うける板の塑性崩壊について”学会論 報 107 号

5）横尾，坂本，宮村，“鉛直荷重と水平荷重を受ける弾・塑 性架構の安定限界耐力についで学会論報 124 号

6）坂本，宮村，“鋼構造骨組の弾・塑性域に少ける変形々安 定性に関守当考察”第且報, 学会論報 113 号

7）若林, 松井, “矩形ラーメンの弾塑性安定について（その 2)" 学会諭報号外, 昭和 40 年 9 月 


\title{
EFFECT OF STRAIN-HARDENING ON STEEL STRUCTURE
}

\author{
by Dr. YOSHITSURA YOKOO*, Dr. JUN SAKAMOTO** \\ and ATUNORI MIYAMURA***, Members of A.I.J.
}

In current experimental researches on inelastic behavior of steel framed structure a marked increase in the ultimate strength and ductility in load-deflection relationship has been observed. This tendedcy may be mainly caused by strain-hardening of the material.

In the previous reports the authors proposed the elastic-plastic analysis of steel frames and discussed the instability problems of partly plastic frame in absence of strain-hardening. Such theoretical approach is apt to tend to a conservative estimate of failure load and be lacking in practical applicabity.

A study herein is made for inelastic analysis of fundamental systems such as cantilever beamcolumns and portal frames taking account of strain-hardening. A role of strain-hardening on steel structures also investigated.

MOMENT-THRUST-CURVATURE RELATIONSHIP AND EFFECTIVE REDUCTION FACTOR.

The stress-strain diagrams are assumed as ideal elastic-plastic curve with linear strain-hardening as shown in Fig. $1 \mathrm{a}$ ) and b). These stress-strain diagrams are corresponding to ordinal mild steel and high tensile steel respectively.

Fig. 2 shows the moment-thrust-curvature relationships for wide-flange section subjected to bending about the major axis including strain-hardening effect, where the dotted lines represent the critical points of flange local buckling. This flange local buckling is assumed to take place when the flange extrene fiber strain is equal to $15 \varepsilon_{y}$ ( $\varepsilon_{y}$ : yielding strain) and $10 \varepsilon_{y}$.

The effective reduction factor $\beta$, defined from the moment-thrust-curvature function, represent the nonlinearity of yielding effect of plastic region in the member. Such moment-effective reduction factor relationship as shown in Fig. 6 can be approximated to the linear relationship both in elastic-plastic and strain-hardening range just as Eq. (2.2) and (2.3).

\section{CANTILEVER BEAM-COLUMN}

The first analytical approach is made for the cantilever beam-columns under constant axial thrust and increasing horizontal loading as shown in Fig. 8.

Typical response curves of the systems by numerical inregration method under help of the digital computer are shown in Fig. 9.

These response curves are classified as follows:

Type $1:$ there exists the instability point in the strain-hardening range.

Type $2:$ the critical point is defined from the compressive flange local buckling.

Type $3:$ there can not be expected the effect of strain-hardening on ultimete strength.

For these three types the following interaction relations $\left(q_{c r} / q_{R}-P / P_{c r}\right)$ are obtainable by using the linearised $m-\beta$ relationship.

Case A (Without stran-hardening)

The load-deflectioncurve in the elastic range is written approximately as Eq. (3.1) and (3.2). Applying the approximate method described in the previous reports to the cantilever beam-column, Eq. (3.3) and (3.4) can be derived with aid of the effective reduction reduction factor $\beta$ in the elastic-plastic range. From these equations and linearised $m-\beta$ relationship the interaction $\left(q_{c r} / q_{R}-P / P_{c r}\right)$ can be obtained as Eq. (3.13) which corresponds to the generalized Rankine formula;

* Prof. of Nagoya University, Nagoya, Japan

** Assist. Prof. of Nagoya University,

*** Assist. Prof. of Nagoya Inst. of Tech. 


$$
\begin{array}{ll}
\frac{q_{c r}}{q_{R}}+\frac{P}{P_{c r}}=1.0 & \\
q_{c r}: \text { elastic instability value } & q_{R}: \text { rigid plastic collapse value } \\
P \text { : axial force } & P_{c r}: \text { lowest elastic buckling load }
\end{array}
$$

A general expression for $\mathrm{Eq},(3.13)$ can be written as;

$$
\frac{q_{c r}}{q_{R}}+K_{1} \cdot \frac{P}{P_{c r}}+K_{2} \sqrt{\frac{P}{P_{c r}}}=1.0
$$

The Rankine formula is corresponding to special case where $K_{1}=1$. and $K_{2}=0$.

On the other hand for rectangular section with relatively larger shape factor a elliptic function is assigned to the approximate $m-\beta$ relation instead of linear $m-\beta$ curve of wide-flange section. Equation ( 3.17 ) is the interaction relation for this case. These relations are shown in Fig. 10 comparing with the numerical results by rigorous solution, where there exists the good agreement between them.

Case B (with strain-hardening)

By applying the same procedure as in Case A, interaction equations (3.18) and (3.19) are derived. Eq. (3.18) is corresponding to the case where ultimate load is determined by instability in the strainhardening range and Eq. (3.19) is to the case that critical load is defined from the flange local buckling. These are plotted in Fig. 10.

The following observation are based on the result of this investigation;

a) The good agreement is obtained between the rigorous solution and approximate analytical value including strain-hardening effect.

b) When column thrust to the lowest buckling load ratio $P / P_{c r}$ is constant, the critical load ratio $q_{c r} / q_{R}$ varies with axial thrust ratio $P / P_{y}$, that is, the ratio $q_{c r} / q_{R}$ increases when $P / P_{y}$ increases.

c) The effective domain of strain-hardening related to $P / P_{c r}$ is shown in Fig. 11, from which the effect of strain-hardening on the ultimate load is most effective when $P / P_{y}$ value equal to about 0.2 .

d) As $P / P_{c r}$ value increases, strain-hardening effect becomes less and then, $P / P_{c r}$ value has an important role on strain-hardening effect in the structure.

e) Taking account of strain-hardening, the Rankine formula is a conservative estimate for ultimate load especially in low $P / P_{c r}$ value range.

\section{DUCTILITY FACTOR}

The relationships between the ductility factor, defined from $\mu=\delta_{c r} / \delta_{y}$, and $P / P_{c r}$ value, are obtainable from Dq. (3.22) for no-strain-hardening and Eq. (3.23) and (3.24) for the case including strain-hardening effect, that is, Eqs. (3.23) and (3.24) is corresponding to the case of Type 1 and 2 respectively.

It can be seen in Fig. 12 that the ductility factor $\mu$ decreases considerably as $P / P_{c r}$ value becomes high, and generally the ductility factor $\mu$ can be expressed as a function of $P / P_{c r}$. The ductility factor of the system can be expected to increase its value according to the effect of strain-hardening. This tendency can be understood by above derived equations and the results of numerical examples. In Fig. 12 the discrepancy between the two should be caused by the analytical approximation.

\section{PORTAL FRAME}

It is possible to apply the above mentioned approximate approach to the portal frame illustrated in Fig. 13. In Fig. 14 a comparison is made between the analytical results and the experimental response curves by Dr. M. Wakabayashi and the good agreement is seen between experimental results and theoretical values including strain-hardening effect. Fig. 15 indicates $q_{c r} / q_{R}-P / P_{c r}$ relationships and Fig. 16, $\mu-P / P_{c r}$ curves for portal frames. Both figures show the same tendency just as the cantilever beam-column.

Further studies have been continued to derive the general conclusion of strain-hardening effect on steel framed structure. 


\title{
TRANSACTIONS OF THE ARCHITECTURAL
}

\author{
INSTITUTE OF JAPAN
}

\section{S Y NOPSIS}

U.D.C. $539.61: 691.714: 691.32$

FUNDAMENTAL STUDY ON BOND BETWEEN STEEL AND CONCRETE

(Part II. On the Deformation of Axially Reinforced

Concrete Prisms Subjected to Tension)

by HIROShI MUGURUMA Prof. of Kyoto Univ. and SHIRO MORITA, Assis. Prof. of Kyoto, Members of A.I.J.

The authors' bond theory developed in Part I of this paper was applied to relatively short reinforced concrete prisms and to long reinforced concrete prisms, both of which were provided with central tensile rein-forcement and subjected to tension.

From the comparison of theoretical and experimental results, the following remarks were obtained.

(1) In the case of short prisms, the steel stress distribution in a given prism was successfully predicted by the theory, and the relationship between the applied load and the relative displacement of the reinforcement with respect to the concrete at the end surfaces gave a measure to evaluate the bond efficiency of reinforcing bars.

(2) In the case of sufficiently long prisms, the mechanism of gradual formation of cracks was explained reasonably by the theory, and the cooperation of concrete in resisting the applied tension force was quantitatively defined by introducing the coefficients $k_{1}$ and $k_{2}$ both in the theory and in the interpretation of test results.

(3) It was suggested that the differences between theoretical and autual results were mainly due to the warping phenomenon of the originally plane concrete section near the end surfaces.

U.D.C. $624.014 .5: 539.38$

STRAIN HARDENING ON STEEL STRUCTURE

(See page 9)

by Dr. JUN. SAKAMOTO, Asisst. Prof. of Nagoya Univ. ATUNORI. MIYAMURA, Assist. Prof., Nagoya Inst. of Tech. MASAO WATANABE, Assistant of Nagoya Univ. Members of A.I.J.

U.D.C. $624.016 .7: 691.7$

\section{STUDIES ON COLUMNS SUBJECT TO CONCENTRIC COMPRESSION. (Part 3)}

by Dr. YOSHITSURA YOKOO, Prof. of Kyoto Univ. Dr. MINORU WAKABAYASHI, Prof. of Kyoto Univ. and Dr. YASUYOSHI SUENAGA Assistant Prof. of Yokohama National Univ. Members of A.I.J.

Strength of columns subject to concentric compression is uppper limit of that of columns subject to combined bending and axial forces,

Many experimental investigations proved that in case of ordinary reinforced concrete this strength of concentric compressioned columns is able to be computed by formula of additional method.

However, in order to use this fomula, it is need that all the stress of concrete in the section of column is uniformal and that compressive failure strain of concrete is larger than the yield point strain of steel, and that more amounts of steels and insufficient covering depth don't make the cracks on the corner. 